\title{
A los 30 años del martirio de San Romero*
}

\section{Pedro Casaldáliga}

Celebrar un jubileo de nuestro San Romero de América es celebrar un testimonio que nos contagia de profecía. Es asumir comprometidamente las causas, la causa por la que nuestro San Romero es mártir. Gran testigo él en el seguimiento del Testigo mayor, el Testigo fiel, Jesús. La sangre de los mártires es aquel cáliz que todos, todas podemos y debemos beber. Siempre y en todas las circunstancias la memoria del martirio es una memoria subversiva.

Treinta años se pasaron de aquella eucaristía plena en la capilla del hospitalito. Aquel día nuestro santo nos escribió: "Nosotros creemos en la victoria de la Resurrección". Y muchas veces dijo, profetizando un tiempo nuevo: "Si me matan, resucitaré en el pueblo salvadoreño". Y, con todas las ambigüedades de la historia en proceso, nuestro San Romero está resucitando en El Salvador, en nuestra América, en el mundo.

Este jubileo debe renovar en todos nosotros y nosotras una esperanza lúcida, crítica, pero invencible. "Todo es gracia", todo es Pascua, si entramos a todo riesgo en el misterio de la cena compartida, la cruz y la Resurrección.

San Romero nos enseña y nos "cobra" que vivamos una espiritualidad integral, una santidad tan mística como política. En la vida diaria y en los procesos mayores de la justicia y la paz, "con los pobres de la tierra", en la familia, en la calle, en el trabajo, en el movimiento popular y en la pastoral encarnada. Él nos espera en la lucha diaria contra esa especie de mara monstruosa que es el capitalismo neoliberal, contra el mercado omnímodo, contra el consumismo desenfrenado. La Campaña de la Fraternidad de Brasil, ecuménica este año, nos recuerda la palabra contundente de Jesús: "Ustedes no pueden servir a dos señores, a Dios y al dinero".

* Texto que don Pedro Casaldáliga envió al pueblo salvadoreño en ocasión del 30. ${ }^{\circ}$ aniversario del martirio de monseñor Romero y que P. Jon Sobrino leyó durante el Congreso de Teología. 
Respondiendo a aquellos que, en la sociedad y en la Iglesia, intentan desmoralizar la Teología de la Liberación, el caminar de los pobres en comunidad, ese nuevo modo de ser Iglesia, nuestro pastor y mártir replicaba: "Hay un 'ateísmo' más cercano y más peligroso para nuestra Iglesia: el ateísmo del capitalismo, cuando los bienes materiales se erigen en ídolos y sustituyen a Dios".

Fieles a los signos de los tiempos, como Romero, actualizando los rostros de los pobres y las urgencias sociales y pastorales, debemos subrayar en este jubileo causas mayores, verdaderos paradigmas algunas de ellas. El ecumenismo y el macroecumenismo, en diálogo religioso y en koinonía universal. Los derechos de los emigrantes contra las leyes de segregación. La solidaridad e intersolidaridad. La gran causa ecológica (precisamente, nuestra Agenda Latinoamericana de este año está dedicada a la problemática ecológica, con un título desafiador: "Salvémonos con el Planeta"). La integración de nuestra América. Las campañas por la paz efectiva denunciando el creciente militarismo y la proliferación de las armas. Urgiendo siempre unas transformaciones eclesiales, con el protagonismo del laicado, que pidió Santo Domingo, y la igualdad de la mujer en los ministerios eclesiales. El desafío de la violencia cotidiana, sobre todo en la juventud, manipulada por los medios de comunicación alienadores y por la epidemia mundial de las drogas.

Siempre y cada vez más, cuando mayores sean los desafíos, viviremos la opción por los pobres, la esperanza "contra toda esperanza". En el seguimiento de Jesús, Reino adentro. Nuestra coherencia será la mejor canonización de San Romero de América, Pastor y Mártir. 